\title{
Literasi Media Kritis dalam Adaptasi Novel Salah Asuhan, ke Sinetron dan Film
}

\author{
I Nyoman Suaka \\ Prodi Pendidikan Bahasa dan Sastra Indonesia, IKIP Saraswati \\ imansuaka@yahoo.co.id
}

\begin{abstract}
Tujuan artikel ini untuk mengetahui hasil adaptasi dari teks novel Salah Asuhan ke film dan sinetron. Masalahnya adalah sejauh mana perubahan teks tersebut dan faktor-faktor apa yang menyebabkan terjadi perubahan?. Masalah tersebut akan dikaji dari teori literasi media kritis dari Devito (2008), sebab peran media dan aktor-aktor media sangat menentukan keberhasilan sebuah program acara. Objek Penelitian adalah novel Salah Asuhan (2008) karya Abdul Muis, film Salah Asuhan (1972), sutradara Asrul Sani dan sinteron Salah Asuhan (1994), sutradara Ami Priyono. Data-data dalam film dan sinetron diperoleh melalui VCD Salah Asuhan. Data-data dikumpulkan dengan teknik catat dan audio visual. Berdasarkan analisis data, maka temuan penelitian adalah, film Salah Asuhan sutradara Asrul Sani merupakan adaptasi murni dari novelnya, sedangkan sinetron Salah Asuhan merupakan adaptasi bebas dari sutradara Ami Priyono. Sinetron tersebut berhasil menggali ide atau gagasan asli pengarang Abdul Muis. Teks novel Salah Asuhan yang beredar di pasaran merupakan karya yang sudah disensor oleh redaksi Volkslectuur, sebuah penerbitan di bawah pemerintah kolonial Belanda. Dengan demikian, melalui literasi media kritis dapat menempatkan teks Salah Asuhan dengan variasi masing-masing sesuai konteks zamannya.
\end{abstract}

kata kunci : novel, film dan sinetron

\section{Critical Media Literacy in the Adaptation of a Salah Asuhan Novel to Soap Operas and films}

The purpose of this article is to find out the adaption results from Salah Asuhan novel text to film and soap operas. The problem is the extent to which the text changes and why changes occur. The problems were examined from the theory of critical media literacy (Devito, 2008), due to a fact that the role of the media and the involvement of the actors determines the success of a show. The object of the research was the novel entitled "Salah Asuhan" (2008) by Abdul Muis, the film of "Salah Asuhan" (1972) directed by Asrul Sani, and the soap opera of "Salah Asuhan" (1994) directed by Ami Priyono. The data were obtained through a pirated movie VCD. The data were collected by note-taking and audio-visual techniques. Based on the analysis, the film directed by Asrul Sani was a pure direct adaptation of his novel, while the soap opera of Salah Asuhan was a free adaptation of the director, Ami Priyono. The opera was succeeded in exploring the original ideas of the author, Abdul Muis. The novel of Salah Asuhan, that circulating in the market, was a work that have been censored by the editor of Volkslectuur, a publication under the Dutch colonial government. Thus, through critical media literacy, it enables to place Salah Asuhan text under respective variations in accordance to the context at that time.

Keywords: novel, film, soap opera

Proses Review : 1 - 20 Mei 2020, Dinyatakan Lolos: 29 Mei 2020 


\section{PENDAHULUAN}

Novel Salah Asuhan karya Abdul Muis merupakan dokumen budaya yang menarik untuk dikaji. Novel yang dterbitkan pertama kali tahun 1928 oleh Volkslectuur (kini Balai Pustaka) itu beberapa kali diadaptasi ke dalam film dan sinetron. Peristiwa yang ditampilkannya adalah keadaan masyarakat Indonesia pada masa penjajahan dalam situasi perjuangan menentang kolonial Belanda. Walaupun karya sastra sebagai hasil imajinasi, tetapi peristiwa yang dilukiskannya itu merupakan gambaran masa lampau dengan segala adat istiadat, budaya, politik dan suasana masa itu. Cerita yang ditulis Abdul Muis waktu itu, terasa aktual saat ini setelah diadaptasi ke dalam film dan sinetron.

Ide-ide pengarang terasa segar dan tidak ketinggalan zaman. Karya-karya Abdul Muis menarik minat para budayawan dan pemerhati kebudayaan populer. Novel Salah Asuhan pernah difilmkan oleh sutradara Asrul Sani (1972) dan disinetronkan oleh sutradara Ami Prijono (1994), tayangan SCTV. Novel ini kembali difilmkan dengan judul yang sama tahun 2018 tayagan RCTI. Untuk keperluan analisis, menggunakan novel Salah Asuhan, film karya Asrul Sani dan sinetron karya Ami Priyono. Walaupun karya novel itu disusun pada awal abad ke-20, namun memasuki abad ke-21 ini kisah-kasih dalam novel-novel itu terasa aktual kembali. Tidak saja masyarakat pecinta Sastra Indonesia yang tertarik dengan novel itu, penonton film dan sinetron. Bahkan sinetron Salah Asuhan yang ditayangkan Surya Citra Televisi (SCTV) dinobatkan sebagai sinetron mini seri terbaik dalam Festival Sinetron Indonesia (FSI) tahun 1994 dengan artis-artis pendukung Ida Iasha, Dolly Marten, Shanaz Haque, dan Rita Zahara. Artis Marisa Harque sebagai produser.

Kemampuan pengarang Muis dalam bidang kebudayaan khususnya di bidang kebahasaan dan kesusastraan sangat mengagumkan. Terbukti dari karya-karya itu, ia lebih menekankan aspek kebudayaan baik kebudayaan tradisi versus kebudayaan modern. Perpaduan dua kebudayaan ini dia alami langsung. Pertama, ia lahir di Bukittinggi, Sumatra Barat dengan lingkungan yang masih bersifat tradisional waktu itu. Kedua, ia aktif di Jawa dalam pergerakan politik melalui organaisasi Sarekat Islam untuk menentang kolonial Belanda, sehingga bergaul dengan orang-orang yang berpikir maju. Terlebih lagi, Moeis pernah pergi ke negri Belanda untuk memperjuangkan nasib bangsanya. Pengalamannya itu memberikan wawasan pada dirinya tentang kebudayaan modern.

Novel Salah Asuhan telah diterjemahkan oleh pengarang asing ke dalam bahasa Jepang., Cina, dan Inggris. Dalam novel Salah Asuhan, Abdul Muis mempertentangkan perbedaan adat dan kebudayaan antara Barat dan Timur (khususnya Minangkabau) dalam soal perkawinan. Konflik kawin campur (Indonesia-Belanda) beserta akibatnya lebih kentara dalam sinetron Salah Asuhan (1994) dibandingkan film yang berjudul sama sama tahun1972.

Abdul Muis dalam Salah Asuhan sengaja mengakhiri kisah kedua tokoh utamanya, Hanafi dan Correi. Correi seorang gadis Eropah meninggal dalam penyesalan yang berkepanjangan dan Hanafi pemuda Minangkabau mengakhiri hidupnya dengan bunuh diri setelah minum racun.

Pengenalan terhadap kebudayaan Barat seperti yang digambarkan Abdul Muis dalam Salah Asuhan bersumber pada peristiwa besar pada tahun 1901 dengan dicanangkannya politik Etis. Gagasan politik ini, menurut Nieuwenhuys (dalam Suwondo, 1997 : 12), memperbesar harapan emansipasi bagi pengarang Indonesia pada khususnya dan kelompok berpendidikan Barat pada umumnya. Politik Etis adalah kebijakan pemerintah Belanda yang bertumpu pada suatu ideologi yang beranggapan bahwa masyarakat jajahan dapat disejahterakan hanya jika masyarakat tersebut dimodernisasikan dengan mempergunakan kebudayaan Barat. Dengan demikian, politik tersebut dimaksudkan untuk menyatukan orang pribumi dan Belanda dalam satu masyarakat dan kebudayaan Barat.

Berdasarkan latar belakang tersebut, maka rumusan masalah dalam penelitian ini, bagaimanakah hasil adaptasi teks novel Salah Asuhan ke film dan sinetron. Faktor-faktor apa saja yang menyebabkan terjadi perubahan teks?. Permasalahan tersebut akan dilihat dari literasi media kritis, mengingat adaptasi tersebut didukung tiga media utama yakni media tulisan (novel), media audio visual dalam tayangan televisi (sinetron) dan tayangan film (layar lebar). Belakangan ini, banyak peneliti yang tertarik dengan alih wahana ini seperti, Suaka (2014 dan 2013)), Pramono (2011), Budianta (2008), dan Eneste (1991).

Peneliti peneliti sebelumnya itu belum mengakaji dari aspek media, terutama literasi media kritis. Suaka dalam artikel berjudul "Transforation of Novel Ronggeng Dukuh Paruk into Film Sang Penari : an Intertekstual Analysis," (Mudra vol 29, no. 3 September 2014) mengkaji dari perbandingan teks. Dalam artikel lain yang juga dimuat Mudra vol 28 no. 2 Juli 2103, Suaka mengkaji sinetron Sitti Nurbaya versi TVRI dan Trans TV dari pendekatan ideologi budaya popular. Peneliti lainnya menggunakan pendekatan wacana dan struktur karya sastra dalam film. Melihat kekosongan itulah, penulis tertarik dari aspek media, karena peran media yang menayangkanya memegang peranan penting dalam keberhasilan adaptasi budaya tersebut. Media juga tidak saja merupakan sebuah wahana, tetapi berkaitan dengan aspek sosiologis, politis dan ideologis.

\section{Literasi Media Kritis}

Literasi media merupakan sebuah topik yang baru di Indonesia karena ledakan teknologi informasi dan komunikasi. Potter dalam Darmastuti dan Junaedi Ed. (2013:4-5) 
menyebutkan kegiatan literasi media terkait tiga isu yaitu, apa yang dimaksud dengan media? (what are media?), apa yang dimaksudan dengan literasi ? (what do we mean by literacy?) dan apa tujuan dari lietrasi media? (what should be the purpose of media literacy?). Beberapa pandangan memahami literasi media dalam konteks peningkatan kecakapan, upaya untuk penguatan pengetahuan di bidang media, pengendalian terhadap pesan media dan lainnya. Menurut Baran (2011:24) literasi media merupakan kecakapan yang melekat dalam diri kita sebagai sesuatu yang terberi (given, taken for granted). Namun, seperti kecakapan yang lain, kecakapan literasi media dapat diperbaiki. Jika kita menilai pentingnya media massa dalam menciptakan dan memelihara budaya yang dapat mendefinisikan kita dalam kehidupan kita, maka kecakapan, literasi media harus selalu ditingkatkan.

Lebih rinci Devito (2008:4) memberikan batasan literasi media sebagai kemampuan untuk memahami, menganalisis, dan memproduksi pesan-pesan komunikasi massa (televisi, film, musik, radio, billboards, periklanan, surat kabar, majalah, buku, website dan blogs, newsgrup dan chatrooms). Devito menggarisbawahi bahwa literasi media merupakan sebuah bentuk pemberdayaan, karena bisa membantu kita untuk menggunakan media lebih cerdas dan kritis, kita bisa memahami, meanganalisis, dan mengevaluasi pesan-pesan yang disampaikan oleh media. Berdasarkan uaraian tersebut, maka teori Devito sangat relevan digunakan untuk membahas persoalan dalam artikel ini. Objeknya sangat jelas berupa buku, televisi, film dan surat kabar, dan dokumen-dokumen tentang Salah Asuhan. Objek penelitian ini akan dipahami, dianalisis dan dievaluasi karena mengandung banyak pesan teks dibalik konteks. Walaupun demikian, teori literasi media ini akan dikembangkan lebih luas lagi yaitu literasi media kritis.

Literasi media kritis seperti disinggung Silverblatt dalam Darmastuti dan Junaedi (2013:1-16) merupakan kecakapan berpikir kritis yang memungkinkan khalayak mampu mengembangkan penilaian yang independen tentang isi media. Berpikir secara kritis tentang isi yang kita konsumsi merupakan hal yang esensial dalam literasi media. Paradigma kritis tidak sekedar menggambarkan mekanisme tersembunyi yang menjelaskan realitas yang diamati, tetapi juga mengkritik kondisi dan menyiratkan rencana perubahan. Berbeda dengan pandangan positivisme yang percaya realitas sosial sebagai sesuatu yang absolut atau padangan interpretatif yang percaya pada relativisme dan setiap individu memiiki perepsi yang unik. Pendekatan kritis mengakui bahwa dunia berisi kondisi-kondisi maerial dimana keyakinan secara konsesus dapat dicapai, tetapi pada saat yang sama ada keunikan dalam setiap individu yang tentu berbeda dengan realitas sosial, bhawa realitas tidak bisa dilihat begitu saja, ada nilai-nilai yang muncul dan menjadi dasar dalam realitas itu (Nasrullah, 2018:68). Secara ontologis, kata Nasurullah (2018) pendekatan kritis ini bersifat realisme historis yang berarti bahwa suatu re- alitas pada mulanya ada dan fkelsibel, akan tetapi seiring perkembangan dan perjalanan waktu realitas itu semakin terbentuk. Faktor-faktor seperti sosial, politik, ekonomi, budaya merupakan faktor yag memberikan sumbangsih terhadap pembentukan realitas yang berada dalam sebuah struktur sehingga mejadi suatu realita yang alamiah dan abadi. Bahkan realitas bentukan yang ada itu danggap sebagai realitas yang nyata.

Konsep ontologis pendekatan kritis di atas akan digunakan dalam menganalisis karya Salah Asuhan, baik dalam bentuk novel, film dan sinsteron. Pendekatan kritis ini akan mengungkapkan realitas yang dibentuk oleh pengarang Abdul Muis, sutradara Asrul Sani dan Ami Priyono, sebab muncul realitas bentukan baru dalam karya-karya tersebut. Faktor-faktor apa saja yang mempengaruhi realitas bentukan tersebut, sangat menarik untuk dibahas melalui pendekatan literasi media kritis. Literasi media perlu diberikan peluang yang lebih luas sebab kondisi selama ini pemirsa atau penonton media lebih banyak bersifat pasif, menerima dan menelan informasi begitu saja. Pemirsa belum menunjukkan sikap kritis terhadap tayangan atau informasi yang beredar di media. Literasi media kritis dapat mencegah berita bohong (hoaks) yang belakangan ini sangat mengkhawatirkan dan merugikan masyarakat.

\section{METODE PENELITIAN}

Penelitian ini tergolong penelitian kualitatif deskriptif sebab analisisnya menggunakan metode kualitatif. Digunakannya metode kualitatif, sesuai dengan pendapat Pawito (2007) karena metode ini bertujuan memahami peristiwa dalam konteks untuk seterusnya memaparkan proses berlangsungnya peristiwa tersebut. Peristiwa dimaksud adalah komunikasi dalam novel, film dan sinetron Salah Asuhan yang ditayangkan di SCTV. Selain itu, model penelitian kualitatif tersebut digunakan karena permasalahan yang diteliti menyangkut teks (verbal, visual dan audiovisual). Penelitian kualitatif merupakan prosedur penelitian yang menghasilkan data deskriptif berupa kata-kata tertulis atau lisan dari orang-orang atau prilaku yang dapat diamati. Penelitian kualitatif lebih mementingkan proses daripada hasil. Hal ini disebabkan bagian-bagian yang sedang diteliti akan jauh lebih jelas, apabila diamati dalam proses.

Sumber data primer adalah teks novel dan teks audiovisual berupa kata-kata dan gambar dalam sinetron Sitti Nurbaya yang ditayangkan stasiun televisi SCTV dan film Salah Asuhan. Mengingat tayangan tersebut telah berlalu, peneliti mencari sumber data yang lain yaitu salinan dalam bentuk kaset VCD Salah Asuhan SCTV. Kaset cakram tersebut hasil mengunduh film dan sinetron Salah Asuhan melalui Youtube (22 Agustus 2019). Sebelumnya, peneliti juga sebagai pemirsa aktif telah menonton film dan sinetron tersebut, termasuk menonton tayangan ulang sinetron. Data primer ini dilengkapi data-data skunder berupa 
dokumen-dokumen media massa seperti majalah Tempo, Femina, Famili dan surat kabar. Dengan demikian, sangat beralasan kalau analisisnya menggunakan pendekatan literasi media kritis.

Pengumpulan data dalam penelitian ini menggunakan teknik observasi dan dokumen. Observasi adalah pengamatan secara intens yang dilakukan dengan membaca, memandang dan menyimak (audio visual) objek penelitian. Teknik membaca yang dilanjutkan dengan teknik pencatatan dilakukan terhadap novel Salah Asuhan karya Abdul Muis terbitan Balai Pustaka tahun 2008. Teknik memandang dan mendengar (audio visual) dilakukan ketika menyaksikan tayangan sinetron Salah Asuhan melalui salinan kaset VCD. Dokumen-dokumen yang digunakan dalam penelitian ini berupa kaset VCD sinetron Salah Asuhan serta novel Salah Asuhan. Analisis data menggunakan metode hermeneutika yaitu analisis yang berifat penafsiran yang ditunjang dengan data dan fakta dalam narasi novel dan film Salah Asuhan. Data-data dan fakta itu dipeoleh melalui sumber kedua yaitu pemberitaan media massa baik berupa artikel, resensi novel, film dan sonetron Salah Asuhaan

\section{ANALISIS DAN INTERPRESTASI DATA}

\section{Sinetron dan Film}

Adegan sinetron Salah Asuhan diawali dengan kaki dan tangan beberapa pemuda aktivis pergerakan terikat oleh rantai. Mereka berjalan sepanjang pasar Solok di Sumatera Barat. Salah seorang dari mereka dengan sorot mata yang tajam menatap penduduk yang tak berdaya. Tiba-tiba, pemuda itu lari, seorang serdadu Belanda menembakkan senapannya. Pemuda yang berkopiah itu terhuyung, dan sempat berjalan beberapa langkah. Akhirnya pemuda tadi jatuh terkapar. Pemuda itu sempat menyelipkan selembar selebaran protes ke tangan seorang ibu yang tengah belanja di pasar. Selebaran itu berisi protes tentang pajak yang dipungut oleh pemerintah kolonial Belanda.

Adegan tersebut berbeda dengan halaman pertama novel Salah Asuhan yang mengambarkan percakapan antara tokoh utama Hanafi dengan Corrie. Percakapan itu terjadi di pinggir lapangan tenis, di bawah pepohonan yang rimbun. Cerita awal dalam buku tersebut dapat disaksikan dalam film layar lebar yang disutradarai Asrul Sani dengan Produser Andhi Ashar. Beberapa aktor dan aktris terkenal masa itu yang terlibat dalam Film Salah Asuhan adalah Dicky Zulkarnaen, Rima Melati, Ruth Pellupesi dan Fifi Young.

Perbedaan alur awal tersebut dimaksudkan agar tayangan sinetron lebih menarik perhatian dengan melibatkan emosi penonton secara dramatis. Hal ini mencerminkan pula bagaimana sutradara Ami Priyono bersama penulis skenario Alex Soeprapto menafsirkan Salah Asuhan. Menurut, Ami Priyono (Tempo, 12 Pebruari 1994), novel karya Abdul Muis ini bukan sekadar cerita tentang percintaan segi tiga dengan latar belakang konflik psikologi antara pribumi dan non pribumi, tetapi juga sebuah cermin perjuangan menentang kolonial. Di balik cinta segi tiga itu pun, muncul persoalan kebudayaan Timur dengan Barat serta kompleksitas psikologi para tokoh-tokohnya.

Produser sinetron Marisa Haque ingin menyajikan cerita Salah Asuhan yang asli, tidak sekedar mengikuti novelnya. Wajah asli Corrie dalam novel yang beredar adalah wajah dan karakter yang sudah disensor yang dilakukan oleh Kepala Volkslectuur (kini penerbit Balai Pustaka) saat itu. Prof. Dr. A. Teeuw, Guru Besar Kesusastraan Melayu dan Indonesia pada Universitas Leiden pernah menanyakan sensor itu langsung kepada Kepala Volkslectuur Prof. Drewes. Dengan jujur Kepala Volkslectuur ini mengakui memang ada pemotongan beberapa adegan saat Corrie berada di rumah pelacuran (Suaka, 2013).

Chudori (dalam Tempo, 12 Pebruari 1994) menilai, adaptasi novel Salah Asuhan ke sinetron cukup sukses karena sutaradara Ami Prijono berhasil menerjemahkan karya yang bersandar pada kekuatan kata, ke karya audio visual yang bersandar pada kekuatan gambar yang bergerak. Untuk mempertahankan latar suasana perjuangan waktu itu sekitar tahun 1920-an, Prijono tidak saja mengangkat tokoh-tokoh yang ada dalam novel Salah Asuhan, tetapi juga menambahkan tokoh Hamidan. Tokoh pemuda yang tidak hadir dalam novel itu adalah seorang pemuda Melayu. Pemuda itulah satu-satunya aktivis pergerakan yang berkawan dengan Hanafi, yang telah dijauhi oleh kawan-kawannya.

Melalui tokoh Hamidan (yang diperankan oleh Ikang Fawzi) sangat tampak perjuangan sosial politik dalam sinetron. Penambahan tokoh dalam filmisasi dan sinetroniasi novel adalah hal yang lumrah dilakukan oleh sutradara untuk lebih menghidupkan cerita. Hal ini juga dilakukan sutradara Dedy Armand dalam sinetron Sitti Nurbaya dengan tokoh baru, Ria Permata Sari yang diperankan oleh Carisa Putri. Demikian juga, dalam sinetron yang sama garapan sutradara Asrul Sani, muncul tokoh isteri Bagindo Sulaeman. Tokoh ini dalam novel tidak ada, hanya diceritakan pengarang Marah Rusli telah meninggal (Suaka, 2013)

Tokoh protagonis Hanafi adalah pemuda Solok Sumatera Barat yang mendapat pendidikan Eropah. Dampak pendidikan itu, Hanafi menganggap bangsanya sebagai orang kampung yang ketinggalan zaman. Isteri Hanafi sebelum menikah dengan Corrie, gadis peranakan Perancis dengan Minang ini adalah Rafiah. Isterinya ini tidak mampu melawan suaminya yang kebelanda-belandaan. Dalam sinetron Salah Asuhan dengan enam episode itu, Hanafi diperankan Dolly Martin, Rapiah oleh Shannas Haque, Corrie diperankan oleh Ida Iasha.

Salah satu adegan yang paling berkesan dalam sinetron 
Salah Asuhan adalah ketika Hanafi minta agar Corrie bertandang ke rumahnya, dan ia minta jawaban segera. Bila tidak, ia akan bunuh diri, lalu mencekik lehernya sendiri. Kemudian kamera mengambil fokus Corrie yang menggelengkan kepala sambil tersenyum. Tidak ada adegan cengeng yang cenderung murahan. Sutradara, Prijono dengan pas menggambarkan bagaimana Corrie yang menaruh perhatian kepada Hanafi, tetapi tetap dalam kepalanya ia sangsi, layakkah ia menikah dengan pemuda itu (Tempo, 12 Pebruari 1994 : 70-71).

Akhirnya, Chudori menyimpulkan bahwa secara umum sutradara Prijono telah sukses membuat sebuah novel menjadi gambar bergerak, menampilkan gambar yang indah, menggunakan bahasa simbol dan dialog yang singkat dan proporsional. Dalam hal ini, sinetron Salah Asuhan lebih menarik daripada film layar lebar yang berjudul sama karya Asrul Sani. Dalam sinetron disuguhkan cerita asli pengarang Abdul Muis. Sutradara Ami Priyono berhasil menggali ide gagasan orisinal pengarang dengan melukiskan Corrie menjadi penyanyi klub malam. Banyak pemuda memuji kecantikannya. Namun, ia mati ditembak oleh salah seorang pengagumnya karena cemburu.

\section{Perubahan Karakter}

Karakter tokoh Corrie tersebut jauh berbeda dengan versi novel. Dalam buku yang mendapat sensor dari penerbit Volslectuur dilukiskan Corrie sempat menjadi pekerja sosial rumah yatim piatu. Ia diserang penyakit kolera dan akhirnya meninggal. Versi dalam buku ini yang kemudian diadaptasi menjadi film garapan sutradara Asrul Sani. Adaptasi ini pun di beberapa episode mengalami perubahan antara yang di buku dengan film. Dalam film Salah Asuhan diceritakan Hanafi dan Corrie pernah sekolah di Eropah, tetapi di dalam novel Abdul Muis disebutkan keduanya pernah sekolah di Betawi (Jakarta). Dalam film, tampak Hanafi dan Corrie berduaan di lembah Anai, sedangkan dalam novel tidak ada adegan semacam itu.

Setelah Corrie pergi ke Betawi, Hanafi akhirnya kawin dengan Rafiah. Suatu hari Hanafi digigit anjing gila, sehingga perlu berobat ke Betawi. Di Betawi, akhirnnya Hanafi bertemu kembali dengan Corrie dalam film. Perjumpaan mereka di Betawi bukan disebabkan digigit anjing gila, tetapi karena Hanafi sedang liburan ke Betawi. Kemudian, ketika Corrie meninggal dunia, Hanafi kembali ke Sumatra Barat. Dalam novel, Abdul Muis melukiskan pertemuan Hanafi dengan keluarganya terjadi di Pasar Malam di Padang. Dalam film yang disutradarai Asrul Sani melukiskan pertemuan tersebut terjadi di pantai. Walaupun terjadi beberapa variasi antara novel dan film pada hakikatnya tema dan amanat novel Salah Asuhan masih terungkap dengan baik dalam film.

Perbedaan karakter tokoh tidak saja muncul di film dan sinetron, tetapi juga pada novel Salah Asuhan. Perbedaan tersebut antara naskah yang ditulis oleh pengarangnya dengan buku yang telah diterbitkan. Pelukisan tokoh Corrie berlainan sekali antara naskah asli dengan yang ada dalam novel sehingga memiliki catatan khusus dalam sejarah sastra Indonesia. Sjafei Radjo Batuah dalam tulisannya yang berjudul "Di Balik Tirai Salah Asuhan" (Pustaka dan Budaya, November- Desember 1964) menyebutkan, naskah karya Muis ini mengalami perbedaan sebelum lolos dari Volkslectuur. Dalam cerita Salah Asuhan sebagaimana terdapat dalam buku yang diterbitkan, peranan Tante Lien tampak tidak begitu penting sebagai nenek comblang. Karena itu belum berhasil menjebak Corrie dalam perangkapnya. Kalau Corrie akhirnya bercerai jaga dari Hanafi, hal tersebut hanyalah semata-mata karena tuduhan yang tidak terbukti bahwa Corrie telah bertindak serong dengan lelaki lain atas perantara Tante Lien. Corrie difitnah oleh Hanafi, sehingga terpaksa menyingkir dari Batavia ke Semarang untuk bekerja pada sebuah panti asuhan. Akhirnya Corrie meninggal dirumah sakit karena diserang penyakit kolera. Dalam cerita ini, jalan kehidupan Corrie mendapat simpati seolah-olah meninggal sebagai pahlawan.

Pelukisan tersebut, menurut Batuah (1964), bagaikan siang dan malam dengan jalan peristiwa dalam naskah asli yang ditulis Abdul Muis. Corrie sebenarnya gadis pesolek yang sangat menyukai pergaulan bebas. Ia sering bergaul dengan seorang pemain keroncong bernama Jance. Mereka malahan pernah berada dalam satu kamar tidur berdua saja. Hidup Corrie mewah dan hal ini sangat menberatkan gaji Hanafi. Pertengkaran tentang hal tersebut menjadi salah satu sebab perceraiannya, disamping rasa perbedaan bangsa yang baru dirasakan setelah mereka bersuami isteri.

\section{Penerbitan Salah Asuhan}

Perubahan jalan cerita seperti itu, menurut Muhamad Akhir Muis, putra bungsu Abdul Muis, karena ayahnya dalam kesulitan hidup waktu itu, sehingga terpaksa mengalah. Akhir Moeis menambahkan, ayah tak mau hidup dibantu kakek sendiri, walaupun kakak tertua saya dalam keadaan sakit. Kompromipun akhirnya harus ditempuh (Tempo, 12 Pebruari 1994). Menurut Akhir Muis, ketika menulis buku Salah Asuhan ayahnya sedang dalam masa pembuangan di Garut, Jawa Barat. "Perjuangan ayah berat sekal. Di Garut hidupnya sangat susah, tanpa penghasilan. Kakak saya tertua yang lahir disana meninggal karena penyakit tetanus. Pada saat itulah ibu mengingatkan ayah untuk meneruskan naskah Salah Asuhan yang ditulis di Belanda dan baru setengah jadi," ujar Akhir Moeis (Femina, 3-9 Pebruari 1994).

Mengenai sikap kompromis ayahnya, Akhir Muis (Femina,3-9 Pebruari 1994) menilai "ayah manusia biasa, bukan manusia super yang mati konyol. Melihat istrinya sengsara, anaknya meninggal,akhirnya ayah kembali ke realita." Dalam keterangan kepada wartawan Famili, Nyonya Soemarsih, istri Abdul Muis menceritakan, da- 
lam keadaan sengsara ia melahirkan anaknya yang pertama dengan bantuan dukun bayi. Berita kelahiran ini cepat tersebar di kalangan keluarga Sarekat Islam. Tidak sedikit yang datang menjenguk dengan membawa beras, jagung, dan ada pula yang memberi uang (Famili, 7-21 Pebruari 1983).

Melihat penderitaan mereka itu, menimbulkan rasa sedih dan gembira di dalam diri Nyonya Muis. "Jangan sakit hati dan merasa dihinakan dengan pemberian ini, terima saja, keadaan kita memang begini adanya." Ujar Abdoel Moeis menimpali perasaan istrinya /Famili, 7-21 Pebruari 1983). Bayi yang baru dilahirkan ini mendadak demam panas yang sangat tinggi dan kaget-kagetan disertai kejang. Sebagai mantan siswa kedokteran, Abdul Muis mengerti apa yang diderita bayinya, tetapi ia tidak berani memberitakan kepada istrinya.

Dalam keadaan panik, Abdul Muis ke Cibatu, menemui temannya yang telah menjadi dokter. Namun dokter Sarwono pun tidak biasa menolongnya lagi dan anaknya meninggal karena tetanus yang dideritanya waktu itu belum ada obatnya. "Bapak sendiri yang membopong jenazah bayi ke makam, dengan pinjaman kain tetangga." tutur Nyonya Abdul Muis dengan sedih (Famili, 7-21 Pebruari 1983).

Kisah sedih dan pilu yang dirasakan Abdul Muis ini akhirnya meluluhkan hatinya, sehingga naskah Salah Asuhan mengalami perubahan. Akhir Muis mengatakan ayah saya ingin menggambarkan wanita Indo zaman itu, tidak diterima dimana-mana, baik pihak Belanda maupun di pihak pribumi. Cerita asli yang disusun Muis tentang Corrie adalah gadis pesolek yang menyukai kehidupan bebas. Versi itu, menurut Akhir Muis tidak terlalu jauh dari cerita yang dikisahkan ibunya kepadanya. (Tempo, 12 Pebruari 1994).

Menurut Nyonya Abdul Muis, seperti yang dituturkan anaknya, Akhir Muis, novel Salah Asuhan yang diterbitkan badan Volkslectuur memang tak seperti yang disalinnya.Nyonya Moeis sendiri masih ingat dengan naskah suaminya yang ia salin sendiri (Tempo, 12 Pebruari 1994). Volkslectuur badan penerbit Belanda itu, tidak suka dengan karakter Corrie yang seperti itu, karena dianggap bias merusak citra orang Belanda. Abdul Muis diminta mengubah naskah itu. Sastrawan yang sesungguhnya anti Belanda tersebut, tidak bisa berbuat banyak karena kesulitan hidup waktu itu. Abdoel Muis akhirnya mengalah pada keinginan Belanda (Femina, 3-9 Pebruari, 1994).

Chudori dan Irawanto dalam tulisannya berjudul "Mencari Wajah Asli Corrie" (Tempo, 12 Pebruari 1994) mengatakan, wajah (karakter) Corrie de Busse dalam novel Salah Asuhan yang beredar luar di masyarakat adalah karakter yang sudah diubah. Perubahan tersebut dilakukan okehh Profesor Drewes, Kepala Volkslectuur. Drewes tidah ingin gadis Eropa kelihatan terlalu negatif.
Guru besar kesusatraan Melayu dan Indonesia Universitas Leiden Belanda, A. Teeuw mengatakan, seandainya naskah itu tidak mendapat campur tangan untuk disesuaikan dengan selera Volkslectuur, maka sebagai hasil sastra, buku itu akan banyak mendapat perhatian. Ia menyayangkan naskah Salah Asuhan itu disensor badan Volkslectuur (Batuah, 1964). Novel ini dikarang oleh Abdul Muis pada permulaan tahun 1927, setelah ia baru saja dijatuhi hukuman eksternir dari daerah-daerah luar Jawa dan Madura. Rupanya konsep karangan ini sudah bulat menyeluruh dalam pikirannya, karena karangannya dapat diselesaikan dalam waktu 20 hari dengan tulisan tangan.

Setelah lama menunggu, tiba-tiba datang seorang pegawai dari Balai Pustaka (Volkslectuur) yang membawa kabar bahwa, harus diadakan revisi dalam cerita Corrie, setelah meninggalkan suaminya. Perintah unruk merevisi itupun dipenuhi oleh Muis. Dalam naskah aslinya, Corrie yang pada mulanya hidup bebas dan pernah menjadi pelacur kemudian mati ditembak pengagumnya. Bagian ini diubah seperti cerita sekarang ini, Corrie setelah meninggalkan suaminya pergi ke Semarang dan bekerja di sebuah panti asuhan.

\section{Politik, Sosial dan Ekonomi}

Berdasarkan analisis literasi media kritis, faktor-faktor yang menyebabkan terjadinya perubahan teks Salah Asuhan karena masalah: politik, ideologi, sosial, budaya dan ekonomi. Faktor politik sangat dominan, menyebabkan novel Salah Asuhan mengalami perubahan karena campur tangan redaksi Volslectuur. Redaksi penerbitan tersebut melakukan sensor karena tidak setuju dengan ide asli pengarang Abdul Muis. Novel tersebut direvisi agar isinya sesuai dengan selera redaksi untuk mempertahankan ideologi kolonial. Buku-buku termasuk karya sastra di luar Salah Asuhan seperti Sitti Nurbaya, Belenggu juga mendapat perlakukan yang sama. Lembaga Volsklectuur tersebut harus bersifat mendukung kebijakan pemerintah kolonial. Kebijakan yang diambil harus menguntungkan pemerintah Belanda untuk melanggengkan kekuasaannya di Indonesia.

Di bidang politik jelas tampak bahwa pendirian Volkslectuur, didasarkan atas usaha menjalankan ideologi pemerintah kolonial di bidang pengajaran. Dengan demikian, wajar jika-karya-karya yang diterbitkannnya bertujuan memberi legitimasi kekuasaan Belanda di tanah jajahan. Menurut Mahayana (2007 : 105-106), beberapa faktor yang menjadi penyebab perjalanan kesusastraan Indonesia berkembang mengikuti ideologi kolonial, diantaranya:

Pendirian Balai Pustaka telah menafikan keberadaan karya-karya terbitan swasta yang secara sepihak dituding sebagai "bacaan liar"

Pemberlakukan sensor melalui Nota Rinkes menyebabkan novel-novel Indonesia, cenderung menampilkan tokoh yang terkesan karikaturis. 
Jaringan distribusi buku dan penyebaran perpustakaan keliling memperkuat keberadaan dan sekaligus pengaruh buku-buku perpustakaan.

Penyebutan bacaan liar karya-karya terbitan di luar Volkslectuur dicurigai oleh pemerintah kolonial akan mengganggu stabilitas keamanan. Sebab, terbitan tersebut di luar kewenangan redaksi yang tumbuhnya menjamur ketika itu. Mengenai tokoh-tokoh yang disebut karikaturis, dapat dilihat bahwa, tokoh Hanafi dan Corrie dalam Salah Asuhan berada di persimpangan jalan, bingung menentukan jalan hidupnya. Penceritaan seperti itu, Mahayana (2007:141) menyebutkan, Salah Asuhan mengungkapkan ideologi yang terpasung.

Kondisi tersebut juga terjadi pada tokoh Samsulbahri dan Datuk Maringgih pada novel Sitti Nurbaya karangan Marah Rusli terbitan Balai Pustaka. Samsulbahri sebagai pemuda ibarat "anjing Belanda" karena berpihak kepada penjajah, melawan bangsanya sendiri. Pelukisan ini sangat jelas diceritakan pada episode episode terakhir. Datuk Maringgih yang awalnya dicaci dan dimaki, kemudian bak "pahlawan" karena mengobarkan semangat perang menentang Belanda. Ideologi politik kolonial secara terselubung sangat berperan melalui karya-karya terbitan Balai Pustaka. Melalui dua novel tersebut, masyarakat pribumi terutama pemudanya diharapkan terpengaruh dengan garis kebijakan kolonial.

Di bidang sosial dan budaya, tema cerita perkawinan campuran ketika itu merupakan sesuatu yang baru dan dianggap tabu, sehingga pengarang ingin menyelamatkan warga pribumi agar tidak tergiur dengan budaya Barat. Perkawinan antarbangsa tersebut menimbulkan pro dan kontra di masyarakat. Sebagian besar dari mereka, ketika itu tidak setuju dengan perkawinan tersebut. Hal ini didasari atas situasi dan kondisi yang ada saat itu, terjadi diskriminasi sosial seperti pengkotak-kotakan golongan pribumi-non pribumi (asing), budaya Timur dengan Barat, tradisi dengan modernisasi, dan golongan penjajah-terjajah. Dari kenyataan itu, masyarakat pribumi selalu dirugikan. Hal seperti itulah yang tidak dikehendaki oleh pengarang Abdul Muis. Amanat yang tersirat dalam Salah Asuhan adalah menghapus diskriminasi, saling menghargai perbedaan budaya dan mengedepankan kesetaraan dalam kehidupan.

Masalah Timur-Barat ini dipertegas lagi oleh Abdullah (1983) yang mengatakan: "Seseorang yang belum terbebas sepenuhnya dari ikatan kultural dan sosialnya sendiri mencoba menyeberang ke dunia lain yang juga enggan menerimanya. Dengan sangat sadar pengarang Abdul Muis menjadikan masyarakat kolonial sebagai setting cerita. Novel ini mencoba mengaktualkan secara imajinatif kemungkinan yang bisa terjadi kalau berbagai aspek tatanan struktural kolonial dipertemukan." Pendapat Abdullah itu menyindir tokoh Hanafi yang mencoba memasuki budaya Barat, tetapi tokoh ini sendiri tidak bisa melepas lingkun- gan adat istiadatnya. Di lingkungan budaya Barat pun, dia tidak bisa diterima, walaupun memiliki kemampuan berbahasa Belanda dengan baik.

Di bidang ekonomi, pengarang dan keluarganya ketika itu mengalami kesulitan hidup. Dengan demikian, pengarang mengambil jalan damai, bisa menerima perubahan-perubahan teks tersebut, walaupun pengarang tetap memiliki iedalisme tinggi dalam perjuangan menentang kolonial. Dalam literasi media kritis, antara novel, film dan sinetron ditemukan sinergi baru sehingga dapat memberikan pencerahan kepada masyarakat bahwa terdapat ideologi penting di balik teks-teks budaya tersebut. Akibat pengaruh kekuasaan, novel Salah Asuhan akhirnya terbit sesuai keinginan redaksi yang terpasung dengan ideologi kolonial. Perubahan dari novel ke film Salah Asuhan itu bersifat adaptasi murni, sedangkan perubahan novel ke sinetron bersifat inovatif dan kreatif. Kreasi baru itu, mampu menggali gagasan asli pengarang Abdul Muis.

\section{SIMPULAN}

Berdasarkan analisis literasi media kritis bahwa terjadi perubahan teks Salah Asuhan baik dalam novel, film dan sinetron. Dalam teks novel, buku Salah Asuhan yang beredar di pasaran tersebut bukan karya asli pengarang Abdul Muis. Cerita Salah Asuhan dalam film karya Asrul Sani, diadaptasi dari novel yang telah mendapat sensor dari penerbit kolonial Belanda, Volkslectuur. Salah Asuhan dalam sinetron karya Ami Priyono, ceritanya mengalami inovasi dan memiliki kreativitas yang tinggi karena tayangan sinteron tersebut mengambil ide asli dari pengarang Abdul Muis.

Faktor-faktor yang menyebabkan terjadinya perubahan teks karena faktor, politik, ideologi, sosial, budaya dan ekonomi. Faktor politik dan ideologi kolonia, menyebabkan novel Salah Asuhan mengalami perubahan karena campur tangan redaksi volslectuur yang tidak setuju dengan ide asli pengarang Abdul Muis. Di samping itu, bukubuku yang diterbitkan oleh badan tersebut harus bersifat mendukung kebijakan pemerintah kolonial. Di bidang sosial dan budaya, tema cerita perkawinan campuran ketika itu merupakan sesuatu yang baru dan dianggap tabu, sehingga pengarang ingin menyelamatkan pemuda pribumi agar tidak tergiur dengan budaya Barat.

Di bidang ekonomi, pengarang dan keluarganya ketika itu mengalami kesulitan hidup. Dengan demikian, pengarang bisa menerima perubahan-perubahan teks tersebut, walaupun pengarang tetap memiliki idealisme tinggi dalam perjuangan menentang kolonial. Dalam literasi media kritis, antara novel, film dan sinetron dapat bersinergi dalam mengekspresikan realitas. Dengan demikian, penonton, pemirsa dan pembaca novel memperoleh wawasan dan pencerahan bahwa terdapat ideologi politik, ekonomi dan budaya di balik teks-teks budaya tersebut. 


\section{DAFTAR RUJUKAN}

Abdullah, Taufik. 1983. "Sastra dan Sejarah : Pantulan Hitoris dan Novel," dalam Horison, XVII, hlm 502-508

Batuah, Sjafei Radjo. 1964. "Di Balik Tirai Salah Asuhan." Dalam Pustaka dan Budaya V (22) : hlm 30-39.

Baran, S. J. 2011. Pengantar Komunikasi Massa : Literasi Media dan Budaya (terjemahan). Jakarta : Salemba Humanika.

Berita Buana. 1984. "Salah Asuhan Diterjemahkan ke dalam Bahasa Jepang,” Thn XIV/9, Selasa 28 Agustus.

Budianta, Melani. 2008. "Representasi Kaum Pinggiran dan Kaptalisme," Dalam Sastra Indonesia Modern Kritik Postkolonial (Foulcher dan Day. Ed) Jakarta : Buku Obor Kerjasama KITLV.

Chudori, Leila.S. 1994. "Menafsirkan Kembali Salah Asuhan." Dalam Tempo, 12 Pebruari.

Chudori, Lelila. S. dan Dwi S Irawanto 1994. "Mencari Wajah Asli Corrie.” Dalam Tempo 12 Pebruari.

Darmastuti, Rini dan Fajar Junaedi, Ed. 2013. Literasi Media dan Kearifan Lokal. Salatiga : Unkris Satya Wacana. Eneste, Pamusuk. 1991. Novel dan Film. Flores : Nusa Indah

Famili. 1983. "Salah Asuhan dan Abdul Muis." Edisi no. 63 tanggal 7 Pebruari hlm 100-103.

Femina. 1994. "Sinetron Salah Asuhan Tragedi Cinta Segi Tiga.” Thn XXII (5), 3-9 Pebruari.

Devito, J.A. 2008. Essentials of Human Comonication. Boston : Pearson Education, Inc.

Mahayana, Maman S. 2007. Ekstrinsikalitas Sastra Indonesia. Jakarta : PT Raja Grafindo Persada.

Moleong, J.X.1995. Penelitian Kualitatif. Bandung : Rosdakarya.

Muis, Abdul. 1987. Salah Asuhan. Jakarta : Balai Pustaka Nasurullah, Rulli. 2018. Etnografi Virtual. Riset Komunikasi, Budaya dan Sosiotenologi di Internet. Bandung : Sosotama Rekatama Media

Pawito. 2007. Penelitian Komunikasi Kualitatif. Yogjakarta : LKis.

Pramono, Dedi. 2011. Naga Bonar Asrul Sani dalam kajian Sosiologi Sastra. Yogjakarta : Pustaka Pelajar.
Sardjono, Parniti. 1996. Dari Karya Sastra Salah Asuhan Kara Abdul Muis ke Sinetron Salah Asuhan Tayangan SCTV Sebuah Trasformasi Penyimpangan atau Kewajaran," Makalah Disampaikan dalam Simposium Ilmu-ilmu Humaniora III UGM Yogjakarta.

Suaka, I N. 2014. "Transformation of Novel Ronggeng Dukuh Paruk into Film Sang Penari ; an Intertextual Analysis," dalam Mudra Jurnal of Art and Culture, vol 29 no 3, September, hlm 323-333.

Suaka, I N. 2013. “ Ideologi Budaya Populer dalam Sinetron Sitti Nurbaya Versi TVRI dan Trans TV," dalam Mudra Jurnal Seni Budaya vol 28 no. 2 Juli 2013 hlm 113-120.

Suwondo, dkk. 1997. Biografi Pengarang Sastra Indonesia. Jakarta : Pusat Pembinaan dan Pengembangan Bahasa Depdikbud. 